\title{
The Thematic Study of Time in Yeats's Mystical System
}

\author{
Shenghua Yang \\ School of Foreign Languages, China West Normal University, Nanchong, China \\ Email: yangshenghua2014@sina.com
}

Received 3 December 2014; accepted 17 December 2014; published 13 January 2015

Copyright (C) 2015 by author and Scientific Research Publishing Inc.

This work is licensed under the Creative Commons Attribution International License (CC BY). http://creativecommons.org/licenses/by/4.0/

c) (i) Open Access

\begin{abstract}
Yeats endeavors to set up the symbolic framework of time in the process of establishing his abstruse and systematic mysticism. $\boldsymbol{A}$ Vision not only provides a pattern according to which temporal events or human types occur or recur, but also reflects the close relation between Yeats's mystical symbolism and the theme of time. The symbolic framework of time-the Gyres and the Great Wheel of mystical system together with their transformed shapes complement and elucidate each other in Yeats's poetry so as to promote his thought of time to a higher level. Three distinctive features of Yeats's poetry - a form of literature, a form of philosophy and a belief in nationality are hammered into the unity of the time theme in his mystical system.
\end{abstract}

\section{Keywords}

Theme of Time, Mystical System, Yeats

\section{Introduction}

William Butler Yeats (1865-1939), as the greatest poet of Ireland and the acknowledged leader of Irish Renaissance, ranks among the most widely admired and intensively studied poet of the twentieth century. Taking a panoramic view of Yeats studies, Yeats's works have been treated as an integrated whole and the thematic studies have taken a center stage. Themes raised in his early work are still present in the later work, developed and explored or revisited from the changing perspectives of age and experience. Creating unity, mythologies, masks, magic, symbolism, Ireland, love, history and prophecy, death and old age are those themes which have been focused on. However, the past thematic studies of Yeats's poetry have almost made no inquires into the motif of time, though it is one of the controlling themes and has taken important position in the thematic studies of Yeats's poetry.

Yeats is deeply influenced by mysticism and occultism, takes Irish mythologies and legends seriously and 
chooses to see everything through a mystical vision. He once said in an 1892 letter, "The mystical life is the centre of all that I do \& all that I think \& all that I write" (Yeats, 1954: p. 303). His works is deeply immersed in the supernatural that it intends to "regenerate the modern world by reopening ancient spiritual wellsprings and reviving primal religious sensibilities” (Kim, 2009: p. 105). The poet also acknowledges that his system in large part is metaphorical and requires symbols to be explained. Many critical works have dealt with Yeats's mysticism and occultism, and regarded him as a member of the Theosophical Society's Esoteric or the Golden Dawn's Inner Order. They tended to interpret his poems in terms of ceremonial magic or hermetic theories. In is noteworthy that Yeats's visionary awareness of time is hidden behind his mysticism and occultism, and can be explored in some symbolic images in his great philosophical work- $A$ Vision.

Yeats endeavors to set up the symbolic framework of time in the process of establishing his abstruse and systematic mysticism. He constructed his cosmological myth when he finished a draft of $A$ Vision. Aspects of this complicated mystical system are frequently reflected in his poetry. Important for us here, is to recognize the elaborate system assumed by Yeats's contemplation of time. A Vision not only provides a pattern according to which temporal events or human types occur or recur, but also reflects the close relation between Yeats's mystical symbolism and the theme of time. What most closely related to the theme of time in the field of Yeats's mystical symbolism is two representative symbolic images - the Gyres and the Great Wheel.

\section{Time and the Gyres}

Yeats develops views about history and destiny and creates his special systematic mysticism in $A$ Vision in which one of the most important symbols - the gyres are deeply concerned. According to Yeats, "gyre is the essential element of growth and life, representing the cyclical nature of the Ultimate Reality with the recurrent pattern of growth and decay, ebb and flow, just like in the Upanishads.” (Izzo, 2009: p. 98). The gyres not only record the course of a single life from birth to death, but trace the rise and fall of civilizations.

In A Vision, the Gyres are pictured as two cones which penetrate each other. These cones, or gyres, represent the opposites in the nature of each person or country or historical period. Each entity of the gyres contains elements of both opposites, categorized as lunar and solar, or subjective and objective, or moral and aesthetic. One gyre is the primary gyre, the other the antithetical gyre. One or the other becomes dominant through space and time. By this system, the past can be classified and the future predicted. Yeats depicts the gyres and the movement of all things in "The Gyres". In the first stanza, Yeats stresses time's destruction on everything with the movement of the gyres. Nothing can last forever as the following lines indicate:

The gyres! The gyres! Old Rocky Face, look forth;

Things thought too long can not be thought,

For beauty dies of beauty, worth of worth,

And ancient lineaments are blotted out. (Yeats, 2008: p. 249)

In the second and the third stanza of this poem, the poet highlights the circular time within the motion of the two cones that:

A great, a more gracious time has gone;

....and all things run

On that unfashionable gyre again. (p. 249)

In the third stanza of Sailing to Byzantium, Yeats moves on his own "gyre" of winding path towards the "monuments of unaging intellect", through the sea of "a dying animal" towards "God's holy fire", as the following lines illuminate:

O sages standing in God's holy fire,

As in the gold mosaic of a wall,

Come from the holy fire, perne in a gyre,

And be the singing-masters of my soul. (p. 163)

Yeats also points out that civilizations rise and decay in terms of foreordained cycles plotted by the gyres of time: "It amuses me to remember that before Phidias and his westward-moving art, Persia fell, and when full moon came round again, amid eastward-moving thought, and brought Byzantium glory, Rome fell; and that at the outset 
of our westward-moving Renaissance Byzantium fell; all things dying each other's life, living each other's death.” (Jeffares, 1984: p. 202). Thus, Yeats's concept of circular time is apparent in his symbolic image- the gyres.

Yeats's creation and illustration of the Gyres in his poetry are very successful. The Gyres existed in Yeats's mystical system have the corresponding forms in his mystical nature and man. Yeats makes intentionally the original gyres and the transformed gyres complement and elucidate each other in his poetry so as to promote his thought of time to a higher level.

The falcon's turning in the widening gyres is a transformed movement of gyres in Yeats's mystical nature. It is apparent in "The Second Coming":

Turning and turning in the widening gyre

The falcon cannot hear the falconer; (p. 158)

The falcon, generally, flies in ever-widening circles away from its trainer and returns when called back. But in the poem, the falcon can no longer hear the falconer's cry. Yeats's falcon travels in gyres and is lost from its return. This thought may derive from Dante's description of how he and Virgil reach the right circle of Hell seated on Geryon's back. Geryon moves in wheeling gyres:

"Of ample circuit, easy thy descent...

As falcon that hath long been on the wing,

But lure nor bird hath seen, while in despair,

The falconer cries 'Ah me! thou stoop’st to earth'.” (Jeffares, 1984: p. 203)

This is the clear illustration of Geryon's emerging from the Abyss with his body shaped like the path of a gyre on a cone. The falcon represents man and civilization, losing touch with Christ, whose birth declares the beginning of the two thousand years of Christianity. Falcon's turning in the widening gyre in Yeats's poem suggests an old age is at end and a new era is coming.

Apart from falcon's turning, Yeats also depicts the existence of Tree of Life and Tree of Knowledge as the transformed cones in "The Two Trees". Harold Bloom interprets this poem as expressing Blakean theme of "Innocence" and "Experience" or "Divine Image" and "Human Abstract” (Bloom, 1970: p. 117). Richard Ellmann gives his comment that the Sephirotic tree as the source of Yeats's two trees has two aspects, "one benign, the reverse side malign. On one side are the sephiroth, on the other the dead Qlippoth” (Jeffares, 1984: p. 38). However, exploring Yeats's mysticism, especially his theory of the Gyres, we may discover that this poem expresses the idea that all things in the universe work out a system of correspondences with one another and coexist as opposites. The first stanza of this poem concerns the Tree of Life that grows within the human heart, and the second stanza is about the Tree of Knowledge that presents a distorted reflection of the reality. All things in the universe exist and change between the Tree of Life and the Tree of Knowledge.

Leda and Mary exist as the transformed cones of Gyres in Yeats's mystical man. Leda got her four children from the eggs after being ravished by Zeus in the form of swan. Helen, one of Leda's children, was destined to be indirectly responsible for the Trojan War that brought the destruction of Troy and the end of an era as the following lines indicate:

A shudder in the loins engenders there

The broken wall, the burning roof and tower

And Agamemnon dead. (p. 182)

Correspondingly, the Virgin Mary gave birth to Jesus Christ whose birth announced the coming of a new age. Yeats expresses this idea in "Veronica's Napkin" and stresses that everything in the universe moves around the pole of the heavens and changes with it. The poet gives his notes on the pole of the heavens when he writes "He Hears the Cry of the Sedge", "The Poet Pleads with the Elemental Powers" and "Veronica’s Napkin" that:

"I have made the Seven Lights, the constellation of the Bear, lament for the Rose, and I have made the Dragon, the constellation Draco, the guardian of the Rose, because these constellations move about the pole of the heavens, the ancient Tree of Life in many countries, and are often associated with the Tree of Life in mythology.” (Jeffares, 1984: p. 63)

It is apparent that the pole of heavens equals the Tree of Life from the poet's notes. He describes a different pole in "Veronica's Napkin", the cross on which Jesus Christ was crucified. The appearance of this new pole 
predicts the occurrence of new things and the coming of a new era.

Yeats was aware of Ballylee Castle from the late 1890s and took possession of the tower in 1917. The tower in Yeats's poetry is closely associated with life and death. The poet's grief at the death is not only reflected in his poem "In Memory of Major Robert Gregory" but manifested in the death himself. Yeats makes announcement in "Blood and the moon" that:

I declare this tower is my symbol; I declare

This widening, gyring, spiring treadmill of a stair is my ancestral stair; (p. 200)

From the above lines we can see that the tower itself is more than the centre of his imagination and the symbol of himself, but the transformed gyre in Yeats's poetry. The present and the ancestral are united in the gyring stair. Life and death change into the opposite with the movement of the gyring tower. What Yeats looks out from the tower is no longer a magic countryside but a systematic movement of time in his mysticism.

\section{Time and the Great Wheel}

The Great Wheel is one of the central ideas in Yeats's systematic mysticism in A Vision. The Great Wheel has twenty-eight spokes, representing a year set out in lunar months. Each spoke signifies the twenty-eight possible selves, each being a mask of the one opposite. The twenty-eight spokes represent phases of each person's life and the phases of each cycle of world history. Each cycle is about two thousand years long. Yeats puts forward the complicated thought in "The Phases of the Moon":

Twenty-and-eight the phases of the moon

The full and the moon's dark and all the crescents

Twenty-and-eight, and yet but six-and-twenty

The cradles that a man must needs be rocked in

For there's no human life at the full or the dark

From the first crescent to the half, the dream

But summons to adventure and the man

Is always happy like a bird or a beast

But while the moon is rounding towards the full

He follows whatever whim's most difficult

Among whims not impossible, and though scarred

As with the cat-o'-nine-tails of the mind

His body moulded from within his body Grows comelier...(p. 138)

The moon governs human life and the nights of a lunar month stand for the successive incarnation. From this standpoint, Yeats perceives time as cyclical rather than linear and, "as in Hindu symbol, the Wheel also represents the cycle of the soul's rebirth” (Izzo, 2009: p. 98).

As for the cyclical movement of history, Yeats mentions the conception of The Great Year. The Great Year or Platonic Year is derived from Plato. Yeats also uses Cicero's definition, based upon Pierre Duhem: "But when the whole of the constellations shall return to the position from which they once set forth, thus after a long interval re-making the first map of the heavens, that may indeed be called the Great Year wherein I scarce dare say how many are the generations of men.” (Jeffares, 1984: p. 232). In the meantime, Yeats adds his own comment on the Great Year: "sometimes divided into lesser periods by the return of the sun and moon to some original position, by the return of a planet or of all planets to some original position, or by their making an astrological aspect with that position; and sometimes it was dissociated from the actual position of the stars and divided into twelve months, each month a brightening and a darkening fortnight, and at the same time perhaps a year with its four seasons." (Jeffares, 1984: p. 232). Yeats stresses his profound thought of the Great Wheel and the Great Year in "The Wheel":

Through winter time we call on spring,

And through the spring on summer call,

And when abounding hedges ring

Declare that winter's best of all;

And after that there's nothing good 
Because the spring-time has not come-

Nor know that what disturbs our blood

Is but its longing for the tomb. (p. 179)

Here the poet depicts time's movement in the change of four seasons and in the conversion of life and death. The poet also reveals a deeper thought through the circular time. Poets, painters and musicians labor at their work, building them with lawless and lawful things alike. They embody the beauty that is beyond the grave. Similarly, Yeats points out that, "these children of the Holy Spirit labor at their moments with eyes upon the shining substance on which Time has heaped the refuse of creation; for the world only exists to be a tale in the ears of coming generations; and terror and content, birth and death, love and hatred, and the fruit of the Tree, are but instruments for that supreme art which is to win us from life and gather us into eternity like doves into their dove-cots.” (Yeats, 1959: pp. 300-301).

Yeats's Great Wheel and its transformed one permeate his poetry. Birds' sail in circles in “The Wild Swans at Coole” and "My Descendants” is a transformed wheel in Yeats's nature depictions:

The nineteenth autumn has come upon me

Since I first made my count;

I saw, before I had well finished,

All suddenly mount

And scatter wheeling in great broken rings

Upon their clamorous wings. (p. 107)

The above lines delineate the cyclical sail of the wild swans at Coole. The wheel, which suggests the broken reality, is in a broken state. It is obvious that the poet is very disappointed with the chaotic reality and hopes to end the chaos with the circular movement of time symbolized by the wild swan's wheeling sail. Birds' wheel is repeated in "My Descendants":

The Primum Mobile that fashioned us

Has made the very owls in circles move; (p. 173)

The poet mentions the Primum Mobile here, the original wheel that causes the revolution of the nine inner spheres around the earth in twenty-four hours. The owls' movement in circles corresponds to the movement of Primum Mobile and implies life's continuation by regeneration.

The wheeling dance is the important transformed wheel in Yeats's human world. The poet depicts the special dance in "Nineteen Hundred and Nineteen”:

When Loie Fuller's Chinese dancers enwound

A shining web, a floating ribbon of cloth,

It seemed that a dragon of air

Had fallen among dancers, had whirled them round

Or hurried them off on its own furious path;

So the Platonic Year

Whirls out new right and wrong,

Whirls in the old instead;

All men are dancers and their tread

Goes to the barbarous clangour of a gong. (p. 177)

It is noted that the wheeling dance in this poem is originated from the wheel of dance that is the great cyclical pattern of the heavenly bodies and is considered as the best established symbolic dance. Time is a movement, according to Plato, and "the stars dance in an intricate pattern" (Plato, 1977: p. 40c). Milton speak of the "starry dance" and the "wandering fires that move/In mystic dance” (Ferber, 1999: p. 50). The traditional "dance of the Hours" is the course of the seasons, but it is an eternal dance; so Milton imagines that "universal Pan/Knit with the Graces and the Hours in dance/Led on the eternal spring” (Ferber, 1999: p. 50). Shelly writes, "But now-” in the eternity of love, "Oh weave the mystic measure Of music and dance and shapes of light, Let the Hours, and the Spirits of might and pleasure Like the clouds and the sunbeams unite.” (Ferber, 1999: p. 50). Yeats' wheeling dance has special function that "whirls out new right and wrong” and "whirls in the old instead". The dancer has 
achieved the ideal state of art from restraint of time and obtained eternity with the movement of circular time.

\section{Conclusion}

Time has become one of literature's primary themes in the twentieth century. Although Yeats was not alone in thematically ordering his poetry by combining the force of time and the pursuit for eternity and ways available to defy time, he was far more involved in this process than most of his contemporaries. The obsession with time makes Yeats's mystical system appear so outstanding in the stage of English and Irish literature. Yeats's visionary awareness of time is implied in his mystical themes and occult symbolism. A Vision, as a summary of Yeats's mystical thought, not only provides a pattern according to which temporal events or human types occur or recur, but also reflects the close relation between Yeats's mystical symbolism and the theme of time. The poet has set up the symbolic framework of time- the Gyres and the Great Wheel in the process of establishing his abstruse and systematic mysticism in A Vision. The original Gyres and Great Wheel of mystical system together with their transformed shapes complement and elucidate each other in his poetry so as to promote his thought of time to a higher level. Three distinctive features of his poetry-a form of literature, a form of philosophy and a belief in nationality are hammered into the unity of the time theme in his mystical system.

\section{References}

Bloom, H. (1970). Yeats. New York: Oxford University Press.

Ferber, M. (1999). A Dictionary of Literary Symbols. Cambridge: Cambridge University Press.

Izzo, D. G. (2009). The Influence of Mysticism on $20^{\text {th }}$ Century British and American Literature. Jefferson: Manufactured \& Company, Inc.

Jeffares, A. N. (1984). A New Commentary on the Poems of W. B. Yeats. London: The Macmillan Press Ltd.

Kim, D.-Y. (2009). Mystical Themes and Occult Symbolism in Modern Poetry. Lewiston: The Edwin Mellen Press.

Plato (1977). Timaeus and Critias. London: Penguin.

Yeats, W. B. (1954). The Letters of W. B. Yeats. London: Rupert Hart-Davis.

Yeats, W. B. (1959). Mythologies. New York: Macmillan.

Yeats, W. B. (2008). The Collected Poems of W. B. Yeats. Hertfordshire: Wordsworth Edition Limited. 
Scientific Research Publishing (SCIRP) is one of the largest Open Access journal publishers. It is currently publishing more than 200 open access, online, peer-reviewed journals covering a wide range of academic disciplines. SCIRP serves the worldwide academic communities and contributes to the progress and application of science with its publication.

Other selected journals from SCIRP are listed as below. Submit your manuscript to us via either submit@scirp.org or Online Submission Portal.
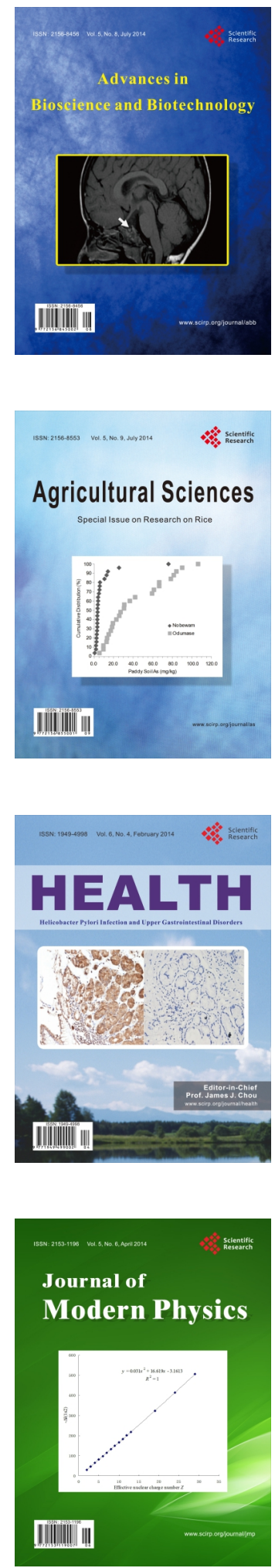
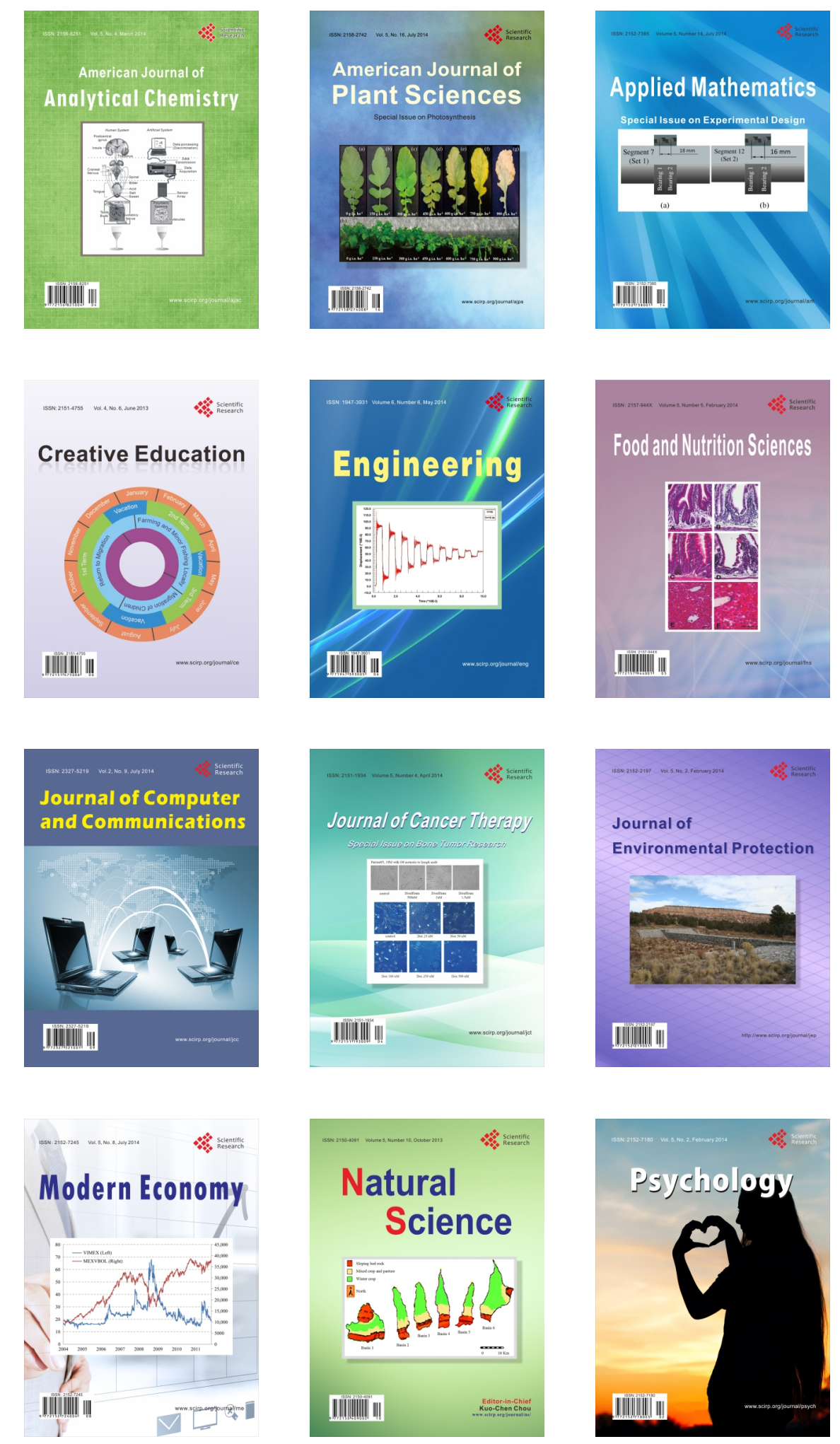